\title{
Independence of stem and leaf hydraulic traits in six Euphorbiaceae tree species with contrasting leaf phenology
}

\author{
Jun-Wen Chen · Qiang Zhang • Xiao-Shuang Li · \\ Kun-Fang Cao
}

Received: 4 December 2008 / Accepted: 19 May 2009 / Published online: 4 June 2009

(C) The Author(s) 2009. This article is published with open access at Springerlink.com

\begin{abstract}
Hydraulic traits and hydraulic-related structural properties were examined in three deciduous (Hevea brasiliensis, Macaranga denticulate, and Bischofia javanica) and three evergreen (Drypetes indica, Aleurites moluccana, and Codiaeum variegatum) Euphorbiaceae tree species from a seasonally tropical forest in south-western China. Xylem water potential at $50 \%$ loss of stem hydraulic conductivity $\left(\mathrm{P} 50_{\text {stem }}\right)$ was more negative in the evergreen tree, but leaf water potential at $50 \%$ loss of leaf hydraulic conductivity $\left(\mathrm{P}^{5} 0_{\text {leaf }}\right)$ did not function as $\mathrm{P} 50_{\text {stem }}$ did. Furthermore, $\mathrm{P} 50_{\text {stem }}$ was more negative than $\mathrm{P} 50_{\text {leaf }}$ in the evergreen tree; contrarily, this pattern was not observed in the deciduous tree. Leaf hydraulic conductivity overlapped considerably, but stem hydraulic conductivity diverged between the evergreen and deciduous tree. Correspondingly, structural properties of leaves overlapped substantially; however, structural properties of stem diverged markedly. Consequently, leaf and stem hydraulic traits were closely correlated with leaf and stem structural properties, respectively. Additionally, stem hydraulic efficiency was significantly
\end{abstract}

J.-W. Chen $(\bowtie) \cdot$ Q. Zhang $\cdot$ X.-S. Li · K.-F. Cao $(\bowtie)$

Kunming Division, Xishuangbanna Tropical Botanical Garden,

The Chinese Academy of Sciences, 88 Xuefu Road,

650223 Kunming, Yunnan, People's Republic of China

e-mail: cjw31412@hotmail.com

K.-F. Cao

e-mail: caokf@xtbg.ac.cn

J.-W. Chen

College of Agronomy and Biotechnology,

Yunnan Agricultural University, 650201 Kunming,

Yunnan, People's Republic of China

Q. Zhang

College of Life Science, South China Normal University,

510631 Guangzhou, Guangdong, People's Republic of China correlated with stem hydraulic resistance to embolism; nevertheless, such a hydraulic pattern was not found in leaf hydraulics. Thus, these results suggest: (1) that the evergreen and deciduous tree mainly diverge in stem hydraulics, but not in leaf hydraulics, (2) that regardless of leaf or stem, their hydraulic traits result primarily from structural properties, and not from leaf phenology, (3) that leaves are more vulnerable to drought-induced embolism than stem in the evergreen tree, but not always in the deciduous tree and (4) that there exists a trade-off between hydraulic efficiency and safety for stem hydraulics, but not for leaf hydraulics.

Keywords Evergreen · Deciduous · Hydraulics ·

Functional structure

\begin{tabular}{|c|c|}
\hline \multicolumn{2}{|c|}{ Abbreviations } \\
\hline$K_{\text {leaf-max }}$ & Maximum leaf hydraulic conductivity \\
\hline$K_{\mathrm{L}-\max }$ & $\begin{array}{l}\text { Maximum leaf area-specific stem hydraulic } \\
\text { conductivity }\end{array}$ \\
\hline$K_{\text {S-max }}$ & $\begin{array}{l}\text { Maximum sapwood area-specific stem hydrau- } \\
\text { lic conductivity }\end{array}$ \\
\hline PLC & Percentage loss of hydraulic conductivity \\
\hline P50 & $\begin{array}{l}\text { Water potential at } 50 \% \text { loss of hydraulic } \\
\text { conductivity }\end{array}$ \\
\hline
\end{tabular}

\section{Introduction}

The issue of divergences in functional trait, ecoclimatic adaptation, and global distribution for deciduous and evergreen tree species has long interested physiologists, ecologists, and biogeographer. Many researches have confirmed that seasonal drought can favor deciduous leaves, and that infertile soils can favor long-lived evergreen leaves (Aerts 1995; Salleo et al. 1997; Eamus 1999; Givnish 2002), but 
the deciduous and evergreen tree species can co-exist in most habitats (Sobrado 1991; Quigley and Platt 2003).

The comparison between the deciduous and evergreen tree species in the same habitats has been widely made. It has been generally accepted that, compared with the evergreen tree species, the deciduous tree species have higher photosynthetic rate, higher relative growth rate, and lower leaf mass per area (Reich et al. 1991; Villar et al. 1995; Cornelissen et al. 1996). On the other hand, lower hydraulic conductivity and lower hydraulic vulnerability have been observed in stems of the evergreen tree species (Choat et al. 2003, 2005; Chen et al. 2009). In contrast, there has also been evidence of the overlap and convergence in stem hydraulic traits for tree species with contrasting phenology (Bucci et al. 2004; Maherali et al. 2004; Choat et al. 2007). Thus, it seems likely that leaf lifespan affects photosynthetic characteristics, but stem hydraulic traits may be independent of leaf phenology.

Nowadays, most studies on hydraulics of tree species have concentrated on property of roots and stems (Brodribb et al. 2003; Maherali et al. 2006; Choat et al. 2007), but relatively few have elucidated leaf hydraulics due to methodological barrier. Nevertheless, recent work has shown that resistance to water transport in leaves accounts for $30-80 \%$ of the total hydraulic resistance of the whole-plant water transport pathway (Becker et al. 1999; Sack et al. 2002), even though the water transport pathway in leaves represents a very small fraction of that in the whole plant. Furthermore, compared with the stems, leaves appear to be more sensitive to cavitations, often losing a substantial fraction of their hydraulic conductivity under non-extreme conditions (Brodribb and Holbrook 2004; Woodruff et al. 2007; Hao et al. 2008). However, leaf life-span has never been taken into account when the comparison of leaf and stem hydraulic vulnerability is made.

Fortunately, many studies have shown that stem hydraulic traits of tree species are closely correlated with wood structure (Hacke et al. 2001; Rosner et al. 2007; Hao et al. 2008). Accordingly, it has been proposed that the divergence in stem hydraulic property for plants with contrasting phenology may result from the difference in stem functional structure regardless of leaf phenology (Chen et al. 2009). Likewise, Sack and Frole (2006) also found that leaf structural diversity was related to hydraulic capacity in tropical rain forest tree, implying that leaf hydraulic traits may depend on leaf structure, and thus may be independent of stem structure. To our knowledge, the comparison of stem hydraulic traits between the deciduous and evergreen tree species has been made, but the comparison of leaf hydraulic traits is yet unavailable.

In the present study, leaf and stem hydraulic traits and their hydraulic-related functional structure were examined in six tree species with contrasting phenology, and the correlation analysis between hydraulic traits and functional structural properties was also made. The six tree species cooccur in a seasonally tropical forest in south-western China.
All of the six tree species belong to a single family (Euphorbiaceae), and thus the experimental results might largely rule out the impact of differences in phylogeny. Our working hypothesis was that there may be substantial differences in hydraulic traits between the evergreen and deciduous tree species, but hydraulic traits may be only related to functional structure regardless of leaf phenology, and thus that leaf hydraulic traits may be independent of stem hydraulic traits.

\section{Materials and methods}

\section{Study site and plant materials}

The study was carried out at Xishuangbanna Tropical Botanical Garden $\left(21^{\circ} 41^{\prime} \mathrm{N}, 101^{\circ} 25^{\prime} \mathrm{E}\right.$, and $570 \mathrm{~m}$ a.s.l.), the Chinese Academy of Sciences in south-western Yunnan, China. The mean annual air temperature is about $21.7^{\circ} \mathrm{C}$ and the annual precipitation is about $1,560 \mathrm{~mm}$. However, it has a strong seasonality that more than $85 \%$ of precipitation occurs between the months of May and October, thereby resulting in a pronounced rainy season from May to October, and a well-defined dry season from November to April. All measurements in the present study were performed in the middle of rainy season between July and August. Because rainfall frequently occurred in the measured periods, thus stems and leaves collected early in the morning were fully hydrated.

Six tree species of Euphorbiaceae [Hevea brasiliensis (Willd. ex A.Juss.) Muell. Arg., Macaranga denticulate (Bl.) Muell. Arg., Bischofia javanica Bl., Drypetes indica (Muell. Arg.) Pax et Hoffm., Aleurites moluccana (L.) Willd., Codiaeum variegatum (L.) A.Juss.] were selected for our study [see Kunming Institute of Botany, The Chinese Academy of Sciences (2006) Flora of Yunnan for species nomenclature]. $H$. brasiliensis is an evergreen tree species in its native habitat of South America, but interestingly it is deciduous in the present region and sheds all leaves at the end of February. M. denticulate and B. javanica are native deciduous tree species, and they shed all leaves at the end of January. New leaves of the three deciduous tree species completely flush before the onset of rainy season. Thus, leaf life-span of the three deciduous tree species is less than 12 months. Correspondingly, D. indica, A. moluccana, and $C$. variegatum are evergreen tree species, and the recorded leaf life-span of A. moluccana, D. indica, and $C$. variegatum at least exceeds 18,21 , and 24 months, respectively. Leaf life-span was calculated according to the method of Navas et al. (2003). The tree height and the diameter at breast height for $C$. variegatum is $2-3 \mathrm{~m}$ and $3-4 \mathrm{~cm}$, respectively. The tree height for the remaining tree species are $5-7 \mathrm{~m}$ and the diameter at breast height are $15-20 \mathrm{~cm}$. 
All sampled tree species selected in our study are fully exposed to sunlight and three to five mature individuals were located for each of the target species.

\section{Stem hydraulic conductivity}

Stem hydraulic conductivity $\left(K_{\mathrm{h}}\right)$ was measured on five to seven branches per species, taken from three to five different individuals. Branches of about $1.5 \mathrm{~m}$ in length were collected early in the morning, recut immediately under water, and returned to laboratory shortly. Branch segments of more than maximum vessel length and 7-9 $\mathrm{mm}$ in diameter were cut underwater, trimmed with a fresh razor blade, and connected to the hydraulic apparatus. Segments were perfused with filtered, $10 \mathrm{mmol}$ oxalic acid solution. The perfusing solution was supplied from a reservoir raised above the flow meter to generate a gravity-induced pressure head of approximately $5 \mathrm{kPa}$. The segment was perfused with solution until a steady-state flow was attained, at which point the hydraulic conductivity of the segment was calculated as $K_{\mathrm{h}}=F L / \Delta P$, where $F$ is the flow rate $\left(\mathrm{kg} \mathrm{s}^{-1}\right), \Delta P$ is the pressure drop (MPa) along the stem segment, and $L$ is the length of stem segment $(\mathrm{m})$. The steady-state flow for stem hydraulic measurements was evaluated by the required time for a given volume of water flow through a pipette connected to the water outlet side of the segments with a transparent rubber tube. If the required time for a given volume of water flow was recorded for three times, and it was relatively stable, we considered the water flow having reached a steady-state flow. Upon completion of the measurement, the segment was perfused with $0.01 \%$ Safranin dye to determine conductive sapwood area. Leaf surface area distal to the stem segment was measured using a leaf area meter (LI-Cor, Lincoln, NE, USA). Sapwood and leaf area were used to calculate sapwood area-specific hydraulic conductivity $\left(K_{\mathrm{S}}, \mathrm{kg} \mathrm{m}^{-1} \mathrm{~s}^{-1} \mathrm{MPa}^{-1}\right)$ and leaf area-specific hydraulic conductivity $\left(K_{\mathrm{L}}, \quad \mathrm{kg} \mathrm{m}^{-1} \mathrm{~s}^{-1}\right.$ $\mathrm{MPa}^{-1}$ ). Because the stems collected early in the morning were fully hydrated, thus maximum $K_{\mathrm{S}}\left(K_{\mathrm{S} \text {-max }}\right)$ and $K_{\mathrm{L}}$ $\left(K_{\mathrm{L}-\max }\right)$ was calculated as $K_{\mathrm{h}}$ divided by sapwood and leaf area, respectively.

In the present study, the segment length of more than the maximum vessel length was selected to reflect intrinsic efficiency of water transport for each species. The maximum vessel length was evaluated by air method measurements as described by Cohen et al. (2003) and Thorne et al. (2006). In brief, an approximately $40 \mathrm{~cm}$ unbranched stem or branch segment was cut directly from the plant. Segment diameters were all between 7 and $9 \mathrm{~mm}$. The segment was connected to the hydraulic apparatus, and filtered; pressurized air at a maximum of $80 \mathrm{kPa}$, which was low enough to avoid inducing cavitations in xylem vessels, was applied to the cut end of segments. Then, the segments were placed under water and incisions were made at 1-2 mm intervals at the air outlet side. The first appearance of a stream of bubbles was evidence of an open xylem vessel, because any water in the open vessels would be pushed out in the first few seconds, and the stable bubbles were then observed. Thus, the distance between two sided of this segment was considered just as the maximum vessel length. Here, it should be pointed out that when low-pressure air is forced through xylem vessels of fresh tissue, air will only pass through open vessels because wet pit membranes will block air flow, and if vessels are already embolized, air will also be able to flow through those vessels, which could compromise the accuracy of continuous vessel length measurements. The measurements of the maximum vessel length were conducted on 7-9 segments from 3-5 individuals of each species.

\section{Stem hydraulic vulnerability curves}

Stem hydraulic vulnerability curve was determined by bench drying method on detached branches (Sperry et al. 1988). Large (about $1.5 \mathrm{~m}$ ) branches from three to five individuals of each species were collected early in the morning, immediately sealed in plastic bags and transported to the laboratory. In the laboratory, these branches were allowed to dehydrate for different periods of time to reach a large range of water potential. The branches were then sealed into double layers of black plastic bags with wet paper towels for at least $2 \mathrm{~h}$ to equilibrate between different parts of the stems. A series of measurements were then made on branch tissue using a tubing apparatus to assess the percentage loss of hydraulic conductivity (PLC) as a result of embolism. The xylem water potential of branch segments was assessed by measuring the water potential of three to five leaves distal to the stem segment. During the measurements, we should carefully distinguish latex from water in some study species. A stem segment was then cut under water and connected to the hydraulic apparatus. For a fixed pressure head, $K_{\mathrm{h}}$ is proportional to volumetric flow rate $\left(J_{\mathrm{v}}\right)$ of water through stem segments, and thus in practice the calculations of PLC were based on $J_{\mathrm{v}}$ rather than $K_{\mathrm{h}}$. After the initial measurement of flow rate $\left(J_{\mathrm{i}}\right)$, the segments were flushed using filtered, $10 \mathrm{mmol}$ oxalic acid solution under a constant pressure of $0.15-0.18 \mathrm{MPa}$ for $10-30 \mathrm{~min}$ to remove embolisms until stable readings of flow rate were reached. The maximum flow rate $\left(J_{\max }\right)$ was then measured using the same pressure head as before. PLC was then calculated as: $\operatorname{PLC}=100\left(J_{\max }-J_{\mathrm{i}}\right) / J_{\max }$. For each branch, three to five segments were selected for measurement, and the total number of measurement for each species was between 50 and 100 . The vulnerability curves were generated for each species by fitting curves for PLC against xylem water potential (Pammenter and Vander Willigen 
1998): $\mathrm{PLC}=100 /(1+\exp (a(\Psi-b)))$, where $\Psi$ is xylem water potential, $a$ is the slope of the line and $b$ is the xylem water potential at which $50 \%$ loss of stem hydraulic conductivity occurs ( $\left.\mathrm{P} 50_{\text {stem }}\right)$. It should be stressed that water potential at $50 \%$ loss of hydraulic conductivity (P50) is commonly used to characterize and interpret interspecific variation in cavitation resistance (Tyree and Ewers 1991).

\section{Leaf hydraulic conductivity}

The branches from three to five individuals of each species were collected early in the morning and leaf hydraulic conductivity $\left(K_{\text {leaf }}\right)$ was then measured according to the method as described by Franks (2006). In brief, $K_{\text {leaf }}=\Delta v /$ $\left(10 \times A_{\text {leaf }} \times\left(\Psi_{1}-\Psi_{2}\right)\right)$, where $\Delta v$ was the volume of sap expressed in the first $10 \mathrm{~s}$ following the step increase in pressure from $\Psi_{1}$ to $\Psi_{2}$, and $A_{\text {leaf }}$ was leaf area $\left(\mathrm{m}^{2}\right)$. The chamber pressure was increased to the balance pressure $\left(\Psi_{1}\right)$ and allowed to equilibrate for about $2 \mathrm{~min}$. The chamber pressure was then rapidly increased to $\Psi_{2}$, and the sap expressed in the first $10 \mathrm{~s}$ was collected and weight on analytical balance to obtain $\Delta v . \Psi_{2}$ was more $0.5 \mathrm{MPa}$ than $\Psi_{1}$ (accurately measured to $\pm 0.01 \mathrm{MPa}$ ). Leaf area was measured with a leaf area meter (LI-Cor, Lincoln, NE, USA). In our experiment, maximum leaf hydraulic conductivity $\left(K_{\text {leaf-max }}\right.$, mmol m${ }^{-2} \mathrm{~S}^{-1} \mathrm{MPa}^{-1}$ ) was obtained due to full hydration of the sampled leaves collected in the early morning.

Leaf hydraulic vulnerability curves

In brief, the branches from three to five individuals of each species were cut early in the morning while leaf water potential $\left(\Psi_{\text {leaf }}\right)$ was fully hydrated, and most leaves were removed except for terminal clusters of six to eight leaves. These branches were then allowed to desiccate very slowly ensuring all leaves remained at similar $\Psi_{\text {leaf }}$. Periodically, branches were bagged and placed in dark for $30 \mathrm{~min}$ to ensure that stomata were closed and $\Psi_{\text {leaf }}$ was homogenous among leaves. Two leaves were then removed to gauge the $\Psi_{\text {leaf }}$ remaining on the branch, after which the remaining leaves were detached to measure $K_{\text {leaf }}$ according to the method described as above: $K_{\text {leaf }}=\Delta v /\left(10 \times A_{\text {leaf }} \times\right.$ $\left.\left(\Psi_{1}-\Psi_{2}\right)\right) . \Psi_{1}$ was defined as $\Psi_{\text {leaf }}$, and leaf hydraulic vulnerability curves were generated by plotting $K_{\text {leaf }}$ against $\Psi_{\text {leaf }}$ with an exponential sigmoid equation: $K_{\text {leaf }}=a /$ $\left(1+\exp \left(-b\left(\Psi_{\text {leaf }}-c\right)\right)\right)$, where $a$ is maximum $K_{\text {leaf }}, b$ is the slope of the line, and $c$ is $\Psi_{\text {leaf }}$ at which $50 \%$ loss of maximum $K_{\text {leaf }}$ occurs ( $\left.\mathrm{P} 50_{\text {leaf }}\right)$. It should be emphasized that this method used to measure $K_{\text {leaf }}$ involves applying a positive pressure to squeeze water out of the leaf, and this may refill cavitations in the leaf xylem when the water is pushed through the leaf at substantial pressure. Conse- quently, this might lead to an overestimation of leaf hydraulic conductivity for dehydrated leaves, and thus to an underestimation of P50. Therefore, cautions should be used when comparing values of $K_{\text {leaf }}$ and P50 given here with values determined using different methods in other studies.

Leaf and stem structural property

Leaves in branches sampled for the measurement of leaf hydraulic traits were also used to determine leaf mass per area (LMA, $\mathrm{g} \mathrm{cm}^{-2}$ ) and leaf anatomical structure. The thickness of the leaf blade, upper epidermis, lower epidermis, palisade mesophyll, and spongy mesophyll were determined from a micrograph at $200 \times$ magnification. Vessel anatomical traits were determined from transverse sections of xylem tissue. Transverse sections of the xylem were made, at least 50-70 vessels diameter was measured in each of the samples to determine mean vessels diameter $\left(D_{\mathrm{m}-\mathrm{v}}\right)$, and the vessels number $(\mathrm{VN})$ per square millimeter was counted. Sapwood density $\left(\mathrm{g} \mathrm{cm}^{-3}\right)$ was determined for each sample that was tested hydraulically. Sapwood with both bark and pith removed was immersed in tap water overnight to saturate the samples. After the surface was wiped dry, the volume of sapwood was measured immediately using the water displacement method. Sapwood density $=M_{\mathrm{d}} / V_{\mathrm{f}}$, where $M_{\mathrm{d}}$ is the oven dry mass (dried at $80^{\circ} \mathrm{C}$ for $72 \mathrm{~h}$ ), and $V_{\mathrm{f}}$ is the fresh volume.

\section{Statistical analysis}

All analyses were performed with the SPSS software package (Chicage, IL), and the variables were given as mean \pm SD. The comparison of hydraulic traits between evergreen and deciduous tree was confirmed by $t$ tests with species nested within leaf habit type. Pearson's correlations were made among hydraulic traits and structural properties. In addition, only the $P$ values of less than 0.05 could be accepted as a significant level.

\section{Results}

The stem hydraulic vulnerability curves indicated that values of $\mathrm{P} \mathrm{O}_{\text {stem }}$ for the three deciduous tree species of $H$. brasiliensis, $M$. denticulate, and B. javantica were -1.27 , -1.14 , and $-1.27 \mathrm{MPa}$, respectively; correspondingly, values of $\mathrm{P}^{2} 0_{\text {stem }}$ for the three evergreen tree species were more negative than $-2.0 \mathrm{MPa}$ (Fig. 1). However, values of $\mathrm{P} 50_{\text {leaf }}$ in the six tree species overlapped considerably when considering leaf habit types (Fig. 2). Thus, compared with the deciduous tree species, $\mathrm{P} 50_{\text {stem }}$ was significantly negative in the evergreen tree species $(P<0.05)$, but $\mathrm{P} 50_{\text {leaf }}$ did not show a significant difference between the evergreen and 

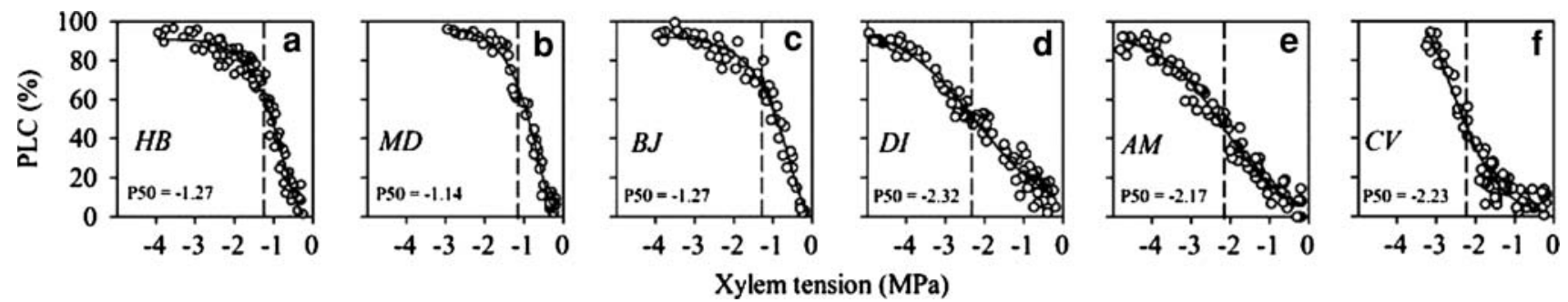

Fig. 1 Vulnerability to water stress-induced embolism in six Euphorbiaceae tree species: $H$. brasiliensis $(H B), M$. denticulate $(M D), B$. javanica $(B J), D$. indica $(D I), A$. moluccana $(A M)$, and $C$. variegatum $(C V)$. Each point represents one measurements and percentage loss of

conductivity (PLC) was plotted against xylem tension for each tree species. The vertical dashed lines indicated the xylem tension at which $50 \%$ loss of hydraulic conductivity occurs (P50)
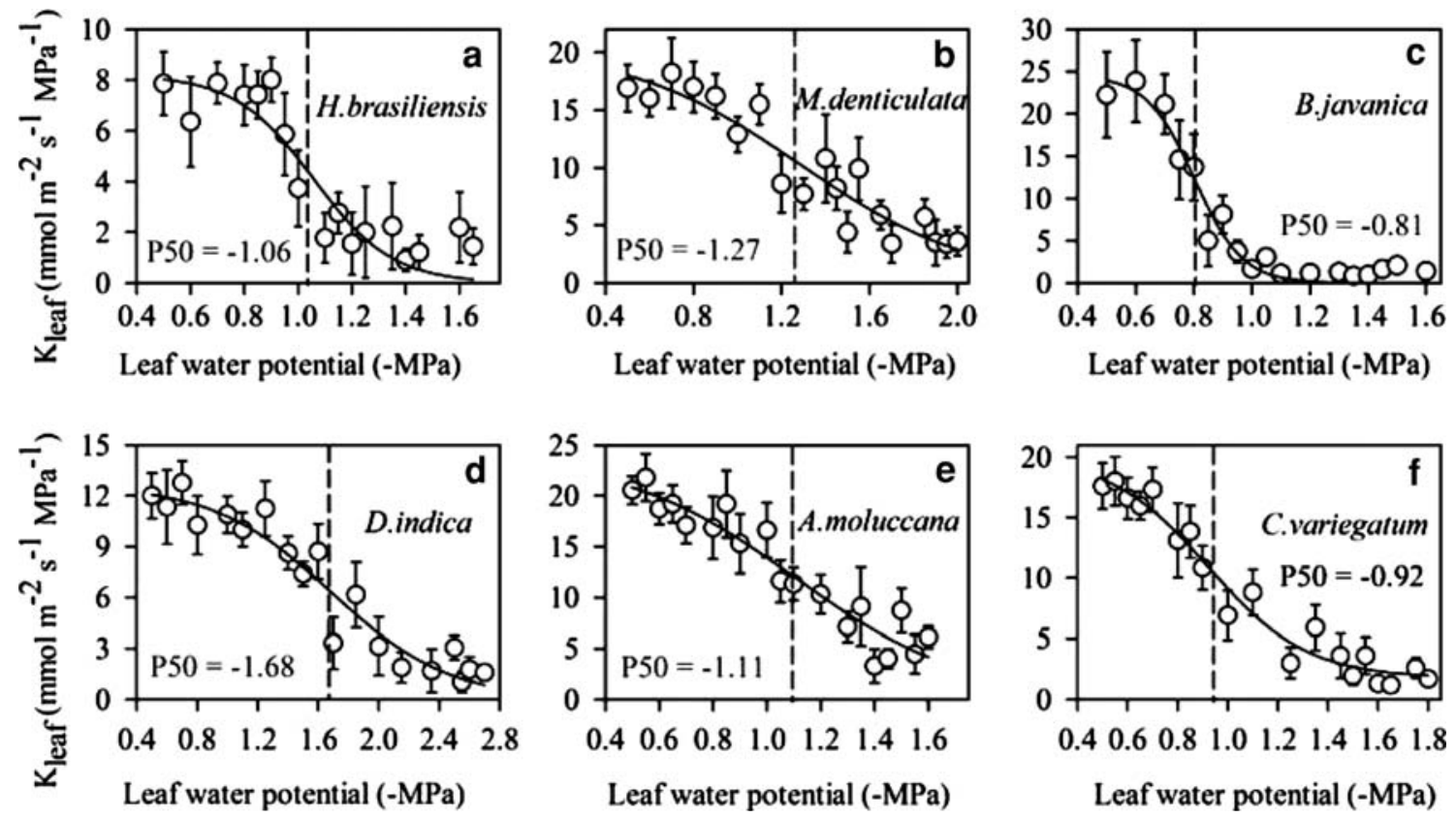

Fig. 2 Leaf hydraulic conductivity $\left(K_{\text {leaf }}\right)$ as a function of leaf water potential for six Euphorbiaceae tree species: H. brasiliensis, $M$. denticulate, $B$. javanica, $D$. indica, A. moluccana, and $C$. variegatum. Values for each point are mean \pm SD of more than ten measurements on the

deciduous tree species (Fig. 3). In addition, P50 $0_{\text {stem }}$ was more negative than $\mathrm{P} 50_{\text {leaf }}$ in the evergreen tree species $(P<0.05)$, but such a pattern was not observed in the deciduous tree species (Fig. 3).

The values of $K_{\text {leaf-max }}$ fluctuated between 8 and $20 \mathrm{mmol} \mathrm{m}^{-2} \mathrm{~s}^{-1} \mathrm{MPa}^{-1}$ in the six tree species, but $K_{\text {leaf- }}$ max did not exhibit a significant difference between plants with contrasting phenology (Fig. 4a). Of the six tree species, the minimum value of $K_{\text {leaf-max }}$ was observed in the deciduous tree species of $H$. brasiliensis, followed by the evergreen tree species of $D$. indica. On the other hand, the values of $K_{\mathrm{L}-\max }$ and $K_{\mathrm{S}-\max }$ were generally lower in the three evergreen tree species except for the evergreen tree species of A. moluccana, the $K_{\mathrm{L}-\max }$ and $K_{\mathrm{S} \text {-max }}$ of which was as high as those of the deciduous tree species (Fig. $4 \mathrm{~b}$, c). Especially, the value of $K_{\mathrm{S} \text {-max }}$ for the deciduous tree slowly dark-desiccated leaves from 3 to 5 individual trees $(n=3-5)$, and a sigmoid function was fitted to the data. The vertical dashed lines indicated the leaf water potential at which $50 \%$ loss of maximum $K_{\text {leaf }}$ occurs (P50)

species was significantly higher than that for the evergreen tree species $(P<0.05$; Fig. $4 \mathrm{c})$.

Structural properties of leaves, such as the thickness of upper epidermis, lower epidermis, palisade mesophyll, spongy mesophyll, and leaf blade and LMA overlapped considerably between the deciduous and evergreen tree species (Table 1). In contrast, structural properties of stems were markedly different between plants with contrasting phenology (Table 1). In comparison with the deciduous tree species, the evergreen tree species generally exhibited higher sapwood density, lower $D_{\mathrm{m}-\mathrm{v}}$, and higher VN per square millimeter.

Person's correlations between hydraulic traits and structural properties were made across the deciduous and evergreen tree species (Table 2). LMA was independent of stem and leaf hydraulic traits. However, negative correlations of 


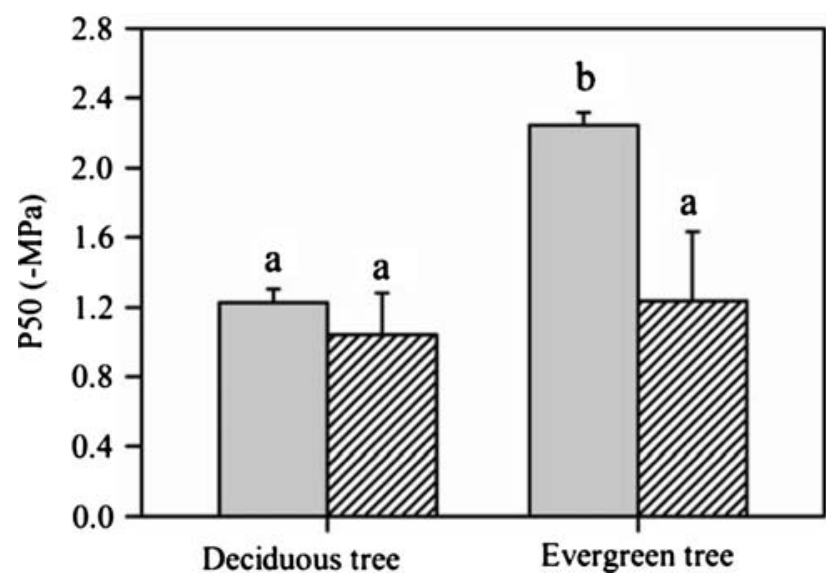

Fig. 3 Water potential at $50 \%$ loss of hydraulic conductivity (P50) for stem (shaded rectangle) and leaf (striped rectangle) in the deciduous and evergreen Euphorbiaceae tree species. The mean \pm SD is shown for the values of P50 $(n=3)$. Within the graph, different lower case letters represent significant differences $(P<0.05, t$ tests $)$

P50 $0_{\text {leaf }}$ with the thickness of upper epidermis, lower epidermis, palisade mesophyll, and leaf blade were observed; in contrast, positive correlations of $K_{\text {leaf-max }}$ with the thickness of upper epidermis, palisade mesophyll, and leaf blade were found across the six tree species with contrasting phenology.

However, no correlations between stem hydraulic traits and leaf structural properties were observed, but stem hydraulic traits were significantly correlated with stem structural properties across the six tree species. Furthermore, no correlations of leaf hydraulic traits with stem anatomical properties, such as $D_{\mathrm{m}-\mathrm{v}}$ and $\mathrm{VN}$, were found across the six tree species. On the other hand, $\mathrm{P} 50_{\text {stem }}$ was significantly correlated with $K_{\mathrm{S} \text {-max }}$, but P50 leaf was uncorrelated with $K_{\text {leaf-max }}$ (Table 2). In addition, no correlation of leaf hydraulic traits with stem hydraulic traits was observed across the six tree species, except that $\mathrm{P} 50_{\text {leaf }}$ was weakly correlated with $K_{\mathrm{L}-\max }$.

\section{Discussion}

The value of $K_{\text {leaf-max }}$ obtained in our experiments is within the range of $K_{\text {leaf-max }}$ reported by Sack and Holbrook (2006), who found that the average value of $K_{\text {leaf-max }}$ in tropical wood angiosperms was about $15 \mathrm{mmol} \mathrm{m}^{-2} \mathrm{~s}^{-1} \mathrm{MPa}^{-1}$. Beyond our expectations that the value of $K_{\text {leaf-max }}$ may be higher in short-lived deciduous leaf, the divergence in $K_{\text {leaf- }}$ ${ }_{\max }$ was not observed between the short-lived deciduous leaf and long-lived evergreen leaf. Nevertheless, it has been reported that the value of $K_{\text {leaf-max }}$ is highly variable even within a life form, varying by tenfold among coexisting tree species (Sack et al. 2005). Furthermore, the focused comparison of $K_{\text {leaf-max }}$ between the deciduous and evergreen tree species has not been made so far. We analyzed the data of the study four tree species of Brodribb and Holbrook (2003b), and also found that there was not a significant difference in $K_{\text {leaf-max }}$ between two deciduous and two evergreen tree species. Thus, it seems likely that leaf life-span may not have an effect on $K_{\text {leaf-max }}$.

In the six tree species, leaf hydraulic resistance to embolism was also highly variable, but long-lived evergreen leaf did not have more negative P50 (Fig. 3), indicating that the capacity of a leaf to resist drought-induced losses of hydraulic function may not affect a leaf's life-span. Originally, we had expected that short-lived deciduous leaf is more vulnerable to drought-induced cavitations, because many researches have shown that, because of the failure to protect from droughtinduced losses of hydraulic function, the deciduous tree species avoids seasonal drought by shedding leaves (Gill and Mahall 1986; Holbrook et al. 1995; Brodribb and Holbrook
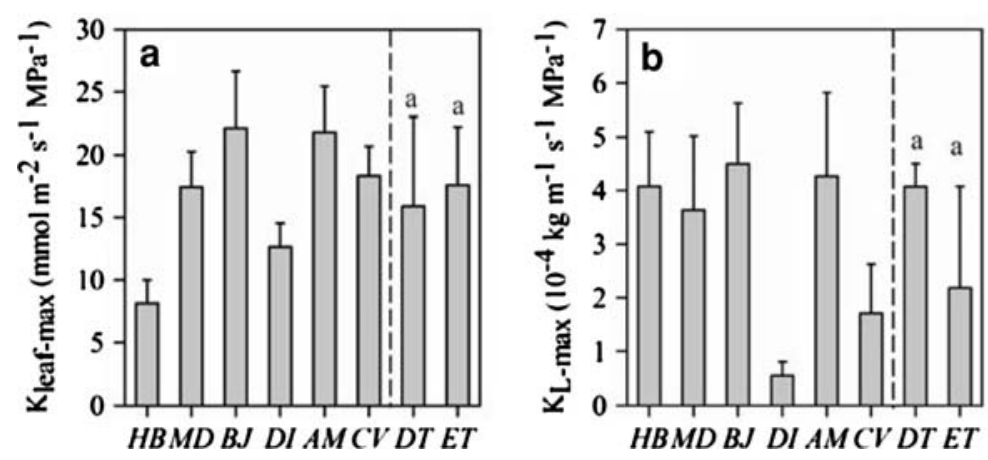

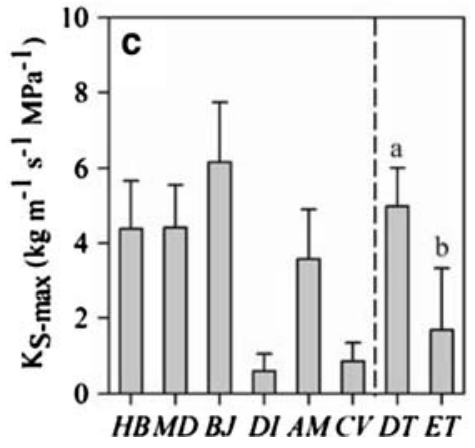

tree. For individual hydraulic traits of six tree species, values are mean \pm SD of more than ten measurements on leaves or stem from 3 to 5 individual trees $(n=3-5)$. For hydraulic traits of deciduous and evergreen tree species, values are mean $\pm \operatorname{SD}(n=3)$ and different lower case letters represent significant differences $(P<0.05, t$ tests $)$ within the graph 
Table 1 Leaf and stem structural traits in six Euphorbiaceae tree species: H. brasiliensis, M. denticulate, B. javanica, D. indica, A. moluccana, C. variegatum

\begin{tabular}{|c|c|c|c|c|c|c|c|c|c|c|}
\hline Tree s & $\begin{array}{l}\text { Leaf } \\
\text { phenology }\end{array}$ & UE ( & LE ( & $\mathrm{PM}$ & $\mathrm{SM}$ & $\mathrm{LT}$ & $\mathrm{LM}$ & $\rho(\mathrm{g}$ & $D_{\mathrm{m}-\mathrm{v}}(\mu \mathrm{m})$ & 2) \\
\hline sis & $\mathrm{De}$ & $25.0 \pm 0.9$ & $28.6 \pm 0.8$ & 100.2 & 98.0 & 4.9 & 74.5 & .04 & 2.6 & 27 \\
\hline der & Deciduous & $26.0=$ & 20.5 & 114.1 & 2 & 7.3 & 8 & 03 & 0.9 & 4.3 \\
\hline javani & Decid & $67.6 \pm$ & $8 \pm 1.8$ & $185.4 \pm 11.0$ & $276.3 \pm$ & $564.1 \pm 6.5$ & 8.0 & .04 & 3.9 & 38 \\
\hline indica & a & $30.4 \pm 0.9$ & $.1 \pm 0.5$ & $80.6 \pm 5.2$ & $155.6 \pm 13.1$ & $289.7 \pm 10.1$ & 105.20 & $0.67 \pm$ & .5 & 135 \\
\hline$a$ & $\mathrm{n}$ & 6 & $9+$ & 12 & 1 & 8 & $82.17 \pm 9.8$ & 03 & 2 & .1 \\
\hline riegatum & Evergreen & $47.1 \pm 2.5$ & 5.2 & 10.8 & 251.5 & 5 & 10 & 55 & $38.0 \pm 5.6$ & 92 \\
\hline
\end{tabular}

The variables are given as mean $\pm \mathrm{SD}(n=3-5)$

$U E$ upper epidermis, $L E$ lower epidermis, $P M$ palisade mesophyll, $S M$ spongy mesophyll, $L T$ leaf thickness, $L M A$ leaf mass per area, $\rho$ sapwood density, $D_{\mathrm{m}-\mathrm{v}}$ mean vessel diameter, $V N$ vessels number per square millimeter

Table 2 Pearson's correlation coefficients between the traits of leaf and stem in six Euphorbiaceae tree species: H. brasiliensis, M. denticulate, B. javanica, D. indica, A. moluccana, C. variegatum

\begin{tabular}{|c|c|c|c|c|c|c|c|c|c|c|c|c|c|c|}
\hline & $\mathrm{P} 50_{\text {leaf }}$ & $K_{\text {leaf-max }}$ & UE & LE & SM & $\mathrm{PM}$ & $\mathrm{LT}$ & LMA & $\mathrm{P} 50_{\text {stem }}$ & $K_{\mathrm{L}-\max }$ & $K_{\mathrm{S}-\max }$ & $\rho$ & $\mathrm{D}_{\mathrm{m}-\mathrm{v}}$ & $\mathrm{VN}$ \\
\hline $\mathrm{P} 50_{\text {leaf }}$ & & -0.37 & $-0.70 *$ & $-0.69 *$ & -0.54 & $-0.91 * * *$ & $-0.73 * *$ & -0.45 & 0.29 & $-0.66^{*}$ & -0.50 & $0.65^{*}$ & -0.36 & 0.30 \\
\hline$K_{\text {leaf-max }}$ & & & $0.76^{* *}$ & 0.31 & 0.47 & $0.71 *$ & $0.62^{*}$ & 0.32 & 0.17 & 0.23 & 0.14 & -0.30 & 0.04 & 0.15 \\
\hline $\mathrm{P} 50_{\text {stem }}$ & & & 0.21 & 0.40 & 0.47 & -0.14 & 0.29 & 0.27 & & $0.66^{*}$ & $0.80 * *$ & $0.79 * *$ & $0.98 * * *$ & $-0.96 * * *$ \\
\hline$K_{\mathrm{L}-\max }$ & & & 0.21 & 0.04 & -0.17 & 0.53 & 0.07 & -0.20 & & & $0.93 * * *$ & $-0.83 * *$ & $0.79 * *$ & $-0.78 * *$ \\
\hline$K_{\mathrm{S}-\max }$ & & & 0.11 & -0.25 & -0.28 & 0.36 & -0.08 & -0.17 & & & & $-0.78 * *$ & $0.91 * * *$ & $-0.85^{* *}$ \\
\hline
\end{tabular}

To facilitate $\log _{10}$-transformation for analysis, $\mathrm{P} 50_{\text {leaf }}$ and P50 ${ }_{\text {stem }}$ values were converted from negatives to positives. $* P<0.10, * * P<0.05, * * * P<0.01$ $P 50_{\text {leaf }}$ leaf water potential at $50 \%$ loss of leaf hydraulic conductivity, $K_{\text {leaf-max }}$ maximum leaf hydraulic conductivity, $P 50_{\text {stem }}$ xylem water potential at $50 \%$ loss of stem hydraulic conductivity, $K_{L-\max }$ maximum leaf area-specific hydraulic conductivity, $K_{S \text {-max }}$ maximum sapwood area-specific hydraulic conductivity, $U E$ upper epidermis, $L E$ lower epidermis, $P M$ palisade mesophyll, $S M$ spongy mesophyll, $L T$ leaf thickness, $L M A$ leaf mass per area, $\rho$ sapwood density, $D_{m-v}$ mean vessel diameter, $V N$ vessels number per square millimeter

2003a). However, the adaptation of short-lived deciduous leaf to seasonal drought was not reflected in the capacity of a leaf to resist embolisms estimated by P50. Based on the previously reported leaf hydraulic vulnerability curves of four tree species with contrasting phenology (Brodribb and Holbrook 2003b), it has not also been found that short-lived deciduous leaf was more vulnerable to water stress-induced cavitations. The overlaps in leaf hydraulic traits for the deciduous and evergreen leaf may result from leaf structural properties, because leaf structural properties overlapped considerably in the six tree species (Table 1).

Evidently, we found that the value of $K_{\text {leaf-max }}$ was related to the thickness of upper epidermis, palisade mesophyll, and leaf blade (Table 2). Similarly, there has been evidence that the value of $K_{\text {leaf-max }}$ correlates with palisade thickness and palisade/spongy mesophyll ratio for tropical rainforest tree species (Sack and Frole 2006), and with total leaf thickness and water storage capacitance per area for temperate woody species (Sack et al. 2003). Meanwhile, some research has shown that leaves with high $K_{\text {leaf-max }}$ tend to have wider xylem conduits in the midrib and higher venation densities (Aasamaa et al. 2001; Sack et al. 2004). Recently, Brodribb et al. (2007) have also found that the post-vein traverse as determined by characters such as vein density, leaf thickness, and cell shape was strongly correlated with the hydraulic conductivity of foliage. The most likely basis for the relationships is that hydraulic traits and mesophyll traits converge for effective whole-leaf design in given habitats (Sack and Holbrook 2006). Species adapted to establishment in high irradiance would benefit from high vein density, conferring higher hydraulic capacity to supply these species higher maximum gas exchange rates, and also providing effective phloem translocation. Interestingly, we also found that leaf hydraulic resistance to embolism was significantly correlated with the thickness of palisade mesophyll (Table 2).

Dissimilarly, stem hydraulic traits displayed a pronounced difference between the plants with contrasting phenology. Obviously, stem hydraulic resistance to drought-induced embolism was weaker in the deciduous tree species (Fig. 3). It is consistent with the findings of Choat et al. (2003) that the deciduous tree species was more susceptible to water stress-induced embolism than the coexisting evergreen tree species. In contrast, the overlap in $\mathrm{P} 50_{\text {stem }}$ was also found in the comparisons between 62 deciduous tree species and 66 evergreen tree species (Maherali et al. 2004). Thus, it has been proposed that the structure of xylem vessels should be seen as an important factor in determining the occurrence of water stress-induced 
embolism (Zimmermann 1983), and that the vulnerability of xylem to water stress-induced embolism is more closely related to the porosity of inter-vessel pit membranes (Choat et al. 2003). More recently, there have been evidences of the strongly positive correlation between $\mathrm{P} 50_{\text {stem }}$ and mean vessel diameter (Maherali et al. 2006; Chen et al. 2009). In addition, our results also confirmed that stem hydraulic resistance to cavitations is significantly related to xylem functional structure, such as $D_{\mathrm{m}-\mathrm{v}}$ and VN (Table 2).

Indeed, the differences in vessels anatomical properties cannot fully explain the divergence in the resistance of xylem to cavitations. Wood density in many tree species from different ecosystems tend to be correlated with a variety of hydraulic-related traits such as the capacity of stem water storage, the efficiency of xylem water transport, the regulation of leaf water status, and the avoidance of turgor loss (Meinzer 2003; Bucci et al. 2004; Gartner and Meinzer 2005). Thus, not surprisingly, xylem becomes more resistant to water stress-induced embolism with increasing wood density (Hacke et al. 2001; Hao et al. 2008). Similarly, sapwood density was significantly correlated with stem hydraulic resistance to cavitations in our study six tree species. Therefore, we think that, regardless of leaf phenology, a series of sapwood characteristics such as diameter and length of vessel, porosity, strength, and durability of pit membrane, and wood density affects stem hydraulic resistance to drought-induced embolisms.

On the other hand, the deciduous tree species generally had higher stem hydraulic efficiency, especially $K_{\mathrm{S} \text {-max }}$ (Fig. 4c). These results are similar to those reported for the evergreen and deciduous tree species from a seasonally dry forest in Venezuela, in which $K_{\mathrm{L}-\max }$ was 2-4 times lower and $K_{\mathrm{S}-\max }$ was 2-6 times lower in the evergreen tree species (Sobrado 1993). In contrast, Goldstein et al. (1989) early found that two evergreen tree species from a Venezuelan tropical savanna had higher $K_{\mathrm{L}-\max }$ and $K_{\mathrm{S} \text {-max }}$ than two co-existing deciduous tree species. More recently, Brodribb et al. (2002) have observed that the values of $K_{\mathrm{S}-\max }$ overlapped substantially for a range of the evergreen and deciduous tree species from a dry forest in Costa Rica, although the highest values recorded were for two deciduous species. Similarly, in our study, $K_{\mathrm{L}-\max }$ for the evergreen tree species of A. moluccana was higher than the deciduous tree species of $H$. brasiliensis and $M$. denticulate, and $K_{\mathrm{S}-\max }$ for the former also approached that for the latter (Fig. $4 \mathrm{~b}, \mathrm{c}$ ). In addition, from the Hagen-Poiseuille law, it is predicted that the wider vessels of tree species would result in higher flow rates for a given pressure gradient. This is confirmed by our results that $K_{\mathrm{L}-\max }$ and $K_{\mathrm{S}-\max }$ were positively correlated with $D_{\mathrm{m}-\mathrm{v}}$ (Table 2). Therefore, the differences in hydraulic efficiency between the evergreen and deciduous tree species possibly rely mainly on the divergence in xylem structure.
Surprisingly, we found that leaf hydraulic traits were uncorrelated with stem hydraulic traits except for the weak correlation of $\mathrm{P} 50_{\text {leaf }}$ with $K_{\mathrm{L}-\mathrm{max}}$, and that leaf and stem hydraulic traits was only correlated with leaf and stem structure, respectively (Table 2). This indicates that leaf and stem each have relatively independent hydraulic system. In addition, $\mathrm{P} 50_{\text {stem }}$ was more negative than $\mathrm{P} 50_{\text {leaf }}$ in the evergreen tree species, but this did not always hold true in the deciduous tree species (Fig. 3). Thus, our result is not fully consistent with the findings of Hao et al. (2008), who found that, because of leaf hydraulic traits being under stronger selective pressure than being stem hydraulic traits in savanna and adjacent forest habitats with high evaporative demand and potentially low soil water availability, leaves were more vulnerable to drought-induced cavitations than terminal braches regardless of genus. However, our findings indicate that leaves function as a safety valve to a greater extent in the evergreen than deciduous tree species.

The correlation of hydraulic vulnerability with hydraulic efficiency has been observed within (Kavanagh et al. 1999; Domec and Gartner 2002; Rosner et al. 2006) and across species (Piñol and Sala 2000; Maherali et al. 2004). Similarly, $\mathrm{P} 50_{\text {stem }}$ was significantly related to $K_{\mathrm{S}-\max }$ within our study six tree species with contrasting phenology. Understandably, tree with higher hydraulic conductivity have wider vessel diameter, and such vessel structure is more susceptible to water stress-induced embolism. This line of reasoning is also confirmed by our results that stem hydraulic efficiency $\left(K_{\mathrm{L}-\max }\right.$ and $\left.K_{\mathrm{S} \text {-max }}\right)$ was positively related to $D_{\mathrm{m}-\mathrm{v}}$, while $\mathrm{P} 50_{\mathrm{stem}}$ was negatively correlated with $D_{\mathrm{m}-\mathrm{v}}$ (Table 2). Actually, this indicates that tree employs different strategies of acquiring water resource based on a trade-off between hydraulic safety and efficiency. Higher hydraulic efficiency might guarantee sufficient acquisition of water resource for tree with higher hydraulic vulnerability before embolism occurs, while low hydraulic vulnerability would ensure tree with low hydraulic conductivity sufficient acquisition of water resource by delaying the occurrence of embolism.

Unexpectedly, one of the most commonly investigated patterns of a trade-off between hydraulic efficiency and resistance to drought-induced cavitations in stem hydraulics was not found in leaf hydraulics of the study six tree species, because $K_{\text {leaf-max }}$ was not correlated with $\mathrm{P} 50_{\text {leaf }}$ (Table 2). In the analysis of the available data for 13 species of ferns, trees, and herbs varying 42 -fold in $K_{\text {leaf-max }}$, Sack and Holbrook (2006) found that $\mathrm{P} 50_{\text {leaf }}$ ranged from -1.3 to $-3.0 \mathrm{MPa}$, and was uncorrelated with $K_{\text {leaf-max }}$. It is widely accepted that stomata closure facilitates preventing the formation of embolisms (Pockman and Sperry 2000; Martínez-Vilalta et al. 2002; Froux et al. 2002). However, we consider that stomata closure may regulate losses of leaf hydraulic function to a larger extent, and losses of stem 
hydraulic function to a lesser extent. Then, the reason for the absence of a trade-off between leaf hydraulic efficiency and safety may be that the existence of stomata regulation for losses of hydraulic function disrupts such a trade-off.

In conclusion, the evident differences between the evergreen and deciduous tree species were found in stem hydraulic traits, but not in leaf hydraulic traits. However, regardless of leaf or stem, their hydraulic traits might result primarily from functional structure, and not from leaf phenology. On the other hand, the findings of this comparative study was that leaves are more vulnerable to droughtinduced loss of hydraulic function than stem among the evergreen tree species, but this was not always the case among the deciduous tree species. In addition, our results also demonstrated that there exists a trade-off between hydraulic efficiency and safety for stem hydraulics, but not for leaf hydraulics, and the reason may be that stomata regulation for drought-induced losses of hydraulic function disrupts a trade-off between leaf hydraulic efficiency and safety.

Acknowledgments This work was funded by Chinese Ministry of Science and Technology through a grant (No. 2006CB403207) under a major 973 project. We thank Zhi-Hui Liu, Xue-Wei Fu, Pei-Li Fu, Jin-Yu Liu and Hong Ma for their experimental assistance. Also, we are deeply grateful to two reviewers for very helpful comments on the manuscript.

Open Access This article is distributed under the terms of the Creative Commons Attribution Noncommercial License which permits any noncommercial use, distribution, and reproduction in any medium, provided the original author(s) and source are credited.

\section{References}

Aasamaa K, Sober A, Rahi M (2001) Leaf anatomical characteristics associated with shoot hydraulic conductance, stomatal conductance and stomatal sensitivity to changes of leaf water status in temperate deciduous trees. Aust J Plant Physiol 28:765-774

Aerts R (1995) The advantages of being evergreen. Trends Ecol Evol 10:402-407

Becker P, Tyree MT, Tsuda M (1999) Hydraulic conductances of angiosperms of versus conifers: transport sufficiency at the whole-plant level. Tree Physiol 19:445-452

Brodribb TJ, Holbrook NM (2003a) Changes in leaf hydraulic conductance during leaf shedding in seasonally dry tropical forest. New Phytol 158:295-303

Brodribb TJ, Holbrook NM (2003b) Stomatal closure during leaf dehydration, correlation with other leaf physiological traits. Plant Physiol 132:2166-2173

Brodribb TJ, Holbrook NM (2004) Diurnal depression of leaf hydraulic conductance in a tropical tree species. Plant Cell Environ $27: 820-827$

Brodribb TJ, Holbrook NM, Gutiérrez MV (2002) Hydraulic and photosynthetic co-ordination in seasonally dry tropical forest trees. Plant Cell Environ 25:1435-1444

Brodribb TJ, Holbrook NM, Edwards EJ, Gutiérrez MV (2003) Relations between stomatal closure, leaf turgor and xylem vulner- ability in eight tropical dry forest trees. Plant Cell Environ 26:443-450

Brodribb TJ, Feild TS, Jordan GJ (2007) Leaf maximum photosynthetic rate and venation are linked by hydraulics. Plant Physiol 144:1890-1898

Bucci SJ, Goldstein G, Meinzer FC, Scholz FG, Franco AC, Bustamante M (2004) Functional convergence in hydraulic architecture and water relations of tropical savanna trees: from leaf to whole plant. Tree Physiol 24:891-899

Chen JW, Zhang Q, Cao KF (2009) Inter-species variation of photosynthetic and xylem hydraulic traits in the deciduous and evergreen Euphorbiaceae tree species from a seasonally tropical forest in south-western China. Ecol Res 24:65-73

Choat B, Ball M, Luly JG, Holtum J (2003) Pit membrane porosity and water stress-induced cavitation in four co-existing dry rainforest tree species. Plant Physiol 131:41-48

Choat B, Ball MC, Luky JG, Holtum JAM (2005) Hydraulic architecture of deciduous and evergreen dry rainforest tree species from north-eastern Australia. Trees 19:305-311

Choat B, Sack L, Holbrook NM (2007) Diversity of hydraulic traits in nine Cordia species growing in tropical forest with contrasting precipitation. New Phytol 175:686-698

Cohen S, Bennink J, Tyree M (2003) Air method measurements of apple vessel length distributions with improved apparatus and theory. J Exp Bot 54:1889-1897

Cornelissen JHC, Castro DP, Hunt R (1996) Seedling growth, allocation and leaf attributes in a wide range of woody plant species and types. J Ecol 84:755-765

Domec JC, Gartner BL (2002) Age- and position-related changes in hydraulic versus mechanical dysfunction of xylem: inferring the design criteria for Douglas-fir wood structure. Tree Physiol 22:91-104

Eamus D (1999) Ecophysiological traits of deciduous and evergreen woody species in the seasonally dry tropics. Trends Ecol Evol 14:11-16

Franks PJ (2006) Higher rates of leaf gas exchange are associated with higher leaf hydrodynamic pressure gradients. Plant Cell Environ 29:584-592

Froux F, Huc R, Ducrey M, Dreyer E (2002) Xylem hydraulic efficiency versus vulnerability in seedlings of four contrasting Mediterranean tree species (Cedrus atlantica, Cupressus sempervirens, Pinus halepensis and Pinus nigra). Ann For Sci 59:409-418

Gartner BL, Meinzer FC (2005) Structure-function relationships in sapwood water transport and storage. In: Holbrook NM, Zwieniecki MA (eds) Vascular transport in plants. Elsevier, Boston, pp 307-331

Gill DS, Mahall BE (1986) Quantitative phenology and water relations of an evergreen and a deciduous chaparral shrub. Ecol Monogr $56: 127-143$

Givnish TJ (2002) Adaptive significance of evergreen vs. deciduous leaves: solving the triple paradox. Silva Fennich 36:1322-1343

Goldstein G, Rada F, Rundel P, Azocar A, Orozco A (1989) Gas exchange and water relations of evergreen and deciduous tropical savanna trees. Ann Sci For 46:448s-453s

Hacke UG, Sperry JS, Pockman WT, Davis SD, McCulloh KA (2001) Trends in wood density and structure are linked to prevention of xylem implosion by negative pressure. Oecologia 126:457-461

Hao GY, Hoffmann WA, Scholz FG, Bucci SJ, Meinzer FC, Franco AC, Cao KF, Goldstein G (2008) Stem and leaf hydraulics of congeneric tree species from adjacent tropical savanna and forest ecosystems. Oecologia 155:405-415

Holbrook NM, Whitbeck JL, Mooney HA (1995) Drought responses of neotropical dry forest trees. In: Bullock SH, Mooney HA, Medina E (eds) Seasonally dry tropical forests. Cambridge University Press, Cambridge, pp 243-276 
Kavanagh KL, Bond BJ, Aitken SN, Gartner BL, Knowe S (1999) Shoot and root vulnerability to xylem cavitation in four populations of Douglas-fir seedlings. Tree Physiol 19:31-37

Kunming Institute of Botany, The Chinese Academy of Sciences (2006) Flora of Yunnan. Sciences Press, Beijing

Maherali H, Pockman WT, Jackson RB (2004) Adaptive variation in the vulnerability of woody plants to xylem cavitation. Ecology 85:2184-2199

Maherali H, Moura CF, Caldeira MC, Willson CJ, Jackson RB (2006) Functional coordination between leaf gas exchange and vulnerability to xylem cavitation in temperate forest trees. Plant Cell Environ 29:571-583

Martínez-Vilalta J, Prat E, Oliveras I, Piňol J (2002) Xylem hydraulic properties of roots and stems of nine Mediterranean woody species. Oecologia 133:19-29

Meinzer FC (2003) Functional convergence in plant responses to the environment. Oecologia 134:1-11

Navas ML, Ducout B, Roumet C, Richarte J, Garnier J, Garnier E (2003) Leaf life span, dynamics and construction cost of species from Mediterranean old-fields differing in successional status. New Phytol 159:213-228

Pammenter NW, Vander Willigen C (1998) A mathematical and statistical analysis of the curves illustrating vulnerability of xylem to cavitation. Tree Physiol 18:589-593

Piñol J, Sala A (2000) Ecological implications of xylem cavitation for several Pinaceae in the Pacific Northern USA. Funct Ecol 14:538-545

Pockman WT, Sperry JS (2000) Vulnerability to xylem cavitation and the distribution of Sonoran desert vegetation. Am J Bot 87:12871299

Quigley MF, Platt WJ (2003) Composition and structure of seasonally deciduous forest in the Americas. Ecol Monogr 73:87-106

Reich PB, Uhl C, Walters MB, Ellsworth DS (1991) Leaf lifespan as a determinant of leaf structure and function among 23 Amazonian tree species. Oecologia 86:16-24

Rosner S, Klein A, Wimmer R, Karlsson B (2006) Extraction of feature from ultrasound acoustic emissions: a tool to assess the hydraulic vulnerability of Norway spruce trunkwood? New Phytol 171:105-116

Rosner S, Klein A, Müller U, Karlsson B (2007) Hydraulic and mechanical properties of young Norway spruce clones related to growth and wood structure. Tree Physiol 27:1165-1178
Sack L, Frole K (2006) Leaf structure diversity is related to hydraulic capacity in tropical rain forest trees. Ecology 87:483-491

Sack L, Holbrook NM (2006) Leaf hydraulics. Annu Rev Plant Biol 57:361-381

Sack L, Melcher PJ, Zwieniecki MA, Holbrook NM (2002) The hydraulic conductance of the angiosperm leaf lamina: a comparison of three measurement methods. J Exp Bot 53:2177-2184

Sack L, Cowan PD, Jaikumar N, Holbrook NM (2003) The 'hydrology' of leaves: coordination of structure and function in temperate woody species. Plant Cell Environ 26:1343-1356

Sack L, Streeter CM, Holbrook NM (2004) Hydraulic analysis of water flow through leaves of sugar maple and red oak. Plant Physiol 134:1824-1833

Sack L, Tyree MT, Holbrook NM (2005) Leaf hydraulic architecture correlates with regeneration irradiance in tropical rainforest trees. New Phytol 167:403-413

Salleo S, Nardini A, Logullo MA (1997) Is sclerophylly of Mediterranean evergreens an adaptation to drought? New Phytol 135:603612

Sobrado MA (1991) Cost-benefit relationships in deciduous and evergreen leaves of tropical dry forest species. Funct Ecol 5:608-616

Sobrado MA (1993) Trade-off between water transport efficiency and leaf life-span in a tropical dry forest. Oecologia 96:19-23

Sperry JP, Donnelly JR, Tyree MT (1988) A method for measuring hydraulic conductivity and embolism in xylem. Plant Cell Environ 11:35-40

Thorne ET, Yong BM, Young GM, Stevenson JF, Labavitch JM, Matthews MA, Rost TL (2006) The structure of xylem vessels in grapevine (Vitaceae) and a possible passive mechanism for the systemic spread of bacterial disease. Am J Bot 93:497-504

Tyree MT, Ewers FW (1991) The hydraulic architecture of trees and other woody plants. New Phytol 119:345-360

Villar R, Held AA, Merino J (1995) Dark leaf respiration in light and darkness of an evergreen and a deciduous plants species. Plant Physiol 107:421-427

Woodruff DR, McCulloh KA, Warren JM, Meinzer FC, Lachenbruch B (2007) Impacts of tree height on leaf hydraulic architecture and stomatal control in Douglas-fir. Plant Cell Environ 30:559-569

Zimmermann MH (1983) Xylem structure and the ascent of sap. Springer, New York 